\title{
The Male Outshopper: An Overlooked Market Segment
}

\author{
JoAnne S. Hopper \\ Thomas J. Lipscomb \\ College of Business Administration \\ Southeastern Louisiana University \\ Hammond, Louisiana.
}

In recent years the phenomenon of consumer outshopping has become of concern to both practitioners and researchers in the field of marketing. Outshopping occurs when consumers leave their local retail area in order to make purchases in nearby localities [2]. Outshopping is known to be a widespread phenomenon. The loss of retail dollars from the local trading area, however, most adversely affects smaller municipalities. Studies have reported that the median percentage of residents of smaller towns who routinely shop at least once a month outside of their local trading area is approximately $65 \%$, as compared to about $20 \%$ of the residents of larger cities who shop beyond the trading area of local merchants $([3],[6])$. In general, the cities and towns patronized by "outshoppers" are larger in size and offer a greater number and variety of retail outlets as compared to those available in the outshoppers' local trading area.

Previous research has demonstrated that variables such as selection, price, and quality were important motives underlying consumer outshopping behavior ([1], [2], $[3],[4],[5],[6])$. In addition, income and age were found to be significant demographic indicators associated with outshopping tendencies with outshoppers generally being younger and more affluent than nonoutshoppers. With respect to psychographic variables, outshoppers have been found to be more fashion-conscious, more self-confident, more optimistic concerning their futures, and to demonstrate greater innovation in their patronage behavior as compared to nonoutshoppers [1].

Although a growing body of literature concerned with the phenomenon of consumer outshopping has begun to emerge, existing studies have been focused upon the identification and description of outshoppers in general and on differentiating outshoppers from nonoutshoppers. Little, if any, attention has been given to attempts to identify important market segments within the general category of outshoppers. The purposes of the present study were to provide a detailed examination of the male outshopper and to attempt to differentiate between men who engage in a significant amount of outshopping and those who do not.

Journal of Business Strategies, Volume 5, Number 2 (Fall 1988) 


\section{Methodology}

\section{Data Collection}

The present study was conducted in a moderate sized town (population - 25,000) located in the south central United States. This locale was considered to be ideal for a study of consumer outshopping as it is located within 45 miles of two major metropoli$\tan$ areas of approximately $1,000,000$ and 250,000 residents. Both metropolitan areas offer numerous major shopping malls and centers and are accessible by interstate highways. The retail outlets in the town in which the data was collected are located primarily in the downtown area, in several community shopping centers, and in a multilevel mall with approximately 80 retail stores including three major department stores. A census approach was utilized to contact area residents. In order to provide a comprehensive database for the study of outshopping, an effort was made to contact each household in the city in which the study was conducted. The official city map was used to identify each street and road within the city limits. With only a few exceptions, each subdivision, road, and apartment complex was canvassed. Thus, an effort was made to contact every household.

Questionnaires were hand-delivered and potential respondents were asked to complete the questionnaire at their leisure. Individuals who were not at home on the initial attempt to contact them were contacted during following week. The majority of completed questionnaires were collected within one hour of being distributed. In all cases the completed questionnaires were collected within 48 hours of being distributed. Every effort was made to contact as many residents as possible. The comprehensiveness of the data collection procedure resulted in a broadly representative sample of consumers. A total of 437 completed usable questionnaires were received from the male respondents, providing a response rate in excess of $90 \%$. All members of this sample were 18 years of age or older and were employed full time.

\section{Measures}

The information collected in the study concerned four areas of interest: (1) attitudes toward shopping in the local market area, (2) attitudes toward outshopping, (3) psychographic profiles, and (4) demographic characteristics. A five point Likert-type scale was used to assess the respondents' attitudes toward the local area, outshopping behavior, and psychographic characteristics.

\section{Analysis}

For the purpose of the present study, an outshopper was defined as a consumer who reported one or more shopping excursions outside the local trading area each month. An inshopper was defined as a consumer who made less than one shopping excursion outside the local trading area each month. Of a total sample of 437 , 299 men were classified as outshoppers and 138 were classified as inshoppers. The data were analyzed by MANOVA to test for overall differences between outshoppers and inshoppers. This multivariate effect indicated a significant difference $(\mathrm{p}<.023)$ between the two groups. Appropriate univariate tests were then performed on the 
responses to individual items in order to investigate differences in male inshopper and outshopper attitudes toward the local market area, outshopping behavior, and psychographic characteristics. The demographic differences between the two types of shoppers were analyzed by means of Chi square tests.

\section{Results and Discussion}

\section{Extent of the Problem}

The study included information on purchases of clothing, groceries, automobiles, home furnishings, and recreation equipment outside of the local trading area. Approximately half of the males reported buying automobiles out of town. In regard to personal clothing, $57 \%$ of the men reported buying $50 \%$ or more of their clothing out of town. Retail expenditures out of town for home furnishings, groceries, and recreational equipment purchases were not as large. About $30 \%$ of the men reported purchasing half or more of their home furnishings and recreational equipment out of town. Less than $10 \%$ of the men bought half or more of their groceries out of town.

The respondents' attitudes toward the hometown merchants' selection of merchandise and pricing were surveyed. In regard to price, the majority of the men indicated that their hometown merchants had prices the same or cheaper than out-of-town merchants. The major problem cited in the study was the lack of selection available through local retailers. More than $50 \%$ of the shoppers stated that clothing and automobile selection was poorer in their home town when compared to out-of-town merchants. Thus, selection appears to be a major motivation for outshopping activity.

\section{Attitudes Toward the Local Trading Area}

The respondents were asked questions concerning their opinions regarding the local trading area and their opinions regarding shopping in area retail stores. The attitudes toward the downtown merchants and mall merchants were both examined. The results of this analysis indicated significant differences between outshoppers and inshoppers on several key dimensions as depicted in Table 1. Specifically, the outshoppers viewed parking as being significantly less convenient, prices as significantly higher in the downtown area, selection of merchandise in the mall location as more inadequate, and shopping in the mall location as less enjoyable as compared to inshoppers. Although both groups indicated their town of residence as being "a nice place to live," there was a significant difference between the groups with outshoppers displaying less favorable attitudes overall. Thus, it appears that the male outshoppers are not as pleased with local merchants as are inshoppers and may be drawn to outof-town merchants due to their dissatisfaction with local retail merchants' offerings and location.

\section{Attitudes Toward Outshopping}

Several questions concerning attitudes toward outshopping activities were addressed in the survey. Respondents were asked about the enjoyment of going out 
of town to shop, time and trouble involved in outshopping, loyalty toward local merchants, and large purchase and gift buying behavior. As indicated in Table 2, the differences among inshoppers and outshoppers were highly significant. Outshoppers were found to be less loyal to local merchants, to enjoy leaving town to shop more, and to belicve that the time and economic costs involved in outshopping excursions were worth the time and money investment required to a greater extent than inshoppers.

Table 1

\section{Differences in the Attitudes of Male Outshoppers and Inshoppers Toward Local Trading Area Merchants}

\begin{tabular}{|lc|} 
& Significance Level \\
Convenience of mall to shoppers & $\mathrm{p}<.023$ \\
Mall well stocked & $\mathrm{p}<.008$ \\
Mall is a fun place to shop & $\mathrm{p}<.014$ \\
Mall prices are high & $\mathrm{p}<.768$ \\
Mall salespersons are helpful & $\mathrm{p}<.344$ \\
Mall parking is adequate & $\mathrm{p}<.040$ \\
Central Business District stores have high prices & $\mathrm{p}<.001$ \\
Downtown stores have a wide selection of merchandise & $\mathrm{p}<.225$ \\
Downtown stores salespersons are friendly & $\mathrm{p}<.188$ \\
It's not convenient to shop downtown & $\mathrm{p}<.030$ \\
It's fun to shop downtown & $\mathrm{p}<.870$ \\
Parking downtown is a problem & $\mathrm{p}<.005$ \\
I enjoy shopping in my hometown & $\mathrm{p}<.005$ \\
\hline
\end{tabular}

analyzed by $t$-tests

Table 2

Differences in the Attitudes of Male Outshoppers and Inshoppers Toward Local Trading Area Merchents

\begin{tabular}{|lc|}
\hline \multicolumn{1}{|c|}{ Attitude } & Significance Level $^{a}$ \\
People should outshop only when they can't find & \\
merchandise in their hometown & $\mathrm{p}<.001$ \\
People should shop where they live & $\mathrm{p}<.001$ \\
Big cities are too impersonal & $\mathrm{p}<.001$ \\
It's too much trouble to shop out of town & $\mathrm{p}<.001$ \\
Shopping in my hometown is convenient & $\mathrm{p}<.001$ \\
Enjoy getting out of town for shopping & $\mathrm{p}<.001$ \\
Considering time and gas, it costs too much to shop & \\
out of town & $\mathrm{p}<.001$ \\
Christmas gifts are bought out of town & $\mathrm{p}<.001$ \\
Buy expensive merchandise out of town & $\mathrm{p}<.001$ \\
\hline
\end{tabular}

\footnotetext{
${ }^{a}$ Analyzed by t-tests
} 
With regard to the purchases of gifts and expensive items, outshoppers indicated a significantly greater disposition to purchase these types of products outside their local trading area. It is in this area that outshoppers and inshoppers displayed the largest difference in behavior and attitudes. The results of this analysis indicated outshoppers to perceive outshopping as more pleasurable and more worth the effort while inshoppers were found to be inclined to remain in their local trading area, in part, to avoid the time and costs of outshopping. This would also imply that local merchants are losing a large number of retail sales for large dollar purchases and gift buying. The local economy would be most adversely affected during major gift buying seasons and with respect to durable goods purchases.

\section{Psychographic Characteristics}

A number of questions posed of the respondents were concerned with psychographic characteristics. These included: fashion orientation, convenience orientation, bargain shopping, and media habits. This analysis indicated the male outshoppers to be more fashion-oriented and less convenience-oriented than the inshoppers. These results indicate that outshoppers may be drawn to larger cities for fashion, while inshoppers stay in town for convenience. Shopping for bargains does not appear to be a significant motivation for outshopping activity. No differences exist between outshopper and inshopper media habits, readership of out-of-town newspapers or listenership to out-of-town radio stations.

\section{Demographic Characteristics}

Striking differences were found between demographic characteristics of outshoppers and inshoppers. Chi-square analysis revealed significant differences in the areas of marital status, age, income, years of residence, and ownership of out-of-town credit cards. Of all the demographic characteristics investigated, income was the only area in which no meaningful differences existed between inshoppers and outshoppers. The demographic profile indicates that a large percentage of the outshoppers are single males and that outshoppers are by far younger than are the inshoppers. The outshoppers report having resided in the area for a relatively brief period of time with the largest percentage having been residents of the area for less than one year. Not surprisingly, the outshoppers also owned a much larger number of aut-of-town credit cards than did inshoppers. Figure 1 presents a summary profile of the demographic and psychographic characteristics of outshoppers.

\section{Summary}

One of the major findings of the present study is that a significant number of men make purchases outside their local trading area on a routine basis. In the present sample, $75 \%$ of the men surveyed reported making purchases of this type two or more times per month. Also quite importantly, the results of this investigation vividly point out that outshoppers and inshoppers differ in meaningful ways. Outshoppers tend to be unmarried and are younger than their inshopper counterparts. The outshoppers 
also report a greater degree of dissatisfaction with local retail outlets and are driven to seek a wider selection and more fashionable merchandise in the nearby larger metropolitan areas.

Figure 1

Demographic and Psychographic

Characteristics of Male Outshoppers

- Residents of town less than five years

- Possess out-of-town retailer charge cards

- Very likely to be single

- Aged 18-45

- Reads out-of-town newspapers

- Likes to be fashionable

- Not concerned with time or bargains

A major difference between the male outshoppers and inshoppers is that the outshoppers believe that the outshopping experience is enjoyable and worth the time and effort, while the inshoppers do not. The outshoppers are less loyal to local merchants and are very likely to make expensive purchases and holiday purchases out of town. It also appears that the male outshopper is less concerned with the amount of time spent in shopping, and is more fashion conscious than is the male inshopper.

\section{Strategic Implications for Retailers}

The results of this study indicate that outshoppers are a viable market segment who have a significant impact on the viability of a retail trading area. The phenomenon of outshopping by its nature creates two potentially competing retail strategies. Small town merchants may strive for outshopper retention while out-of-town merchants engage in retailing strategies designed to attract outshoppers. The following discussion explores such possible strategies for both types of merchants. Supporting figures and tables portray specific steps that retailers may choose to consider when seeking to capture this important market segment.

\section{Small Town Merchants' Strategies}

\section{for Retaining Outshoppers}

The multiplier effect begins to mushroom as dollars flow out of small towns into the pockets of big city merchants. Sales tax collections fall and the result is less money for schools, public works, and special projects. Not only do merchants suffer by depressed sales due to outshopping, but the economy of the entire town is ultimately negatively affected.

Because outshoppers are leaving their local area to seek greater selection, it is important for all of the area merchants to work together to provide better selection 
across product offerings in the local trading area. A truly cooperative effort is needed among retailers. Optimally, this cooperative effort would include promotional campaigns that incorporate a theme of improved selection among merchants. Through advertising, sales promotion, and publicity, the message of better merchandise selection would be communicated to the male outshopper. Merchants would also offer special orders for custom merchandise, and would stock more fashionable items that appeal to a large segment of the outshoppers. It is important to note that pricing does not seem to be a problem. Most outshoppers are not bargain hunters. Thus, the thrust of the local merchants would be a cooperative effort to retain outshoppers as well as an actual change in product selection. The local Chamber of Commerce might also engage in a campaign promoting the increased level of consumer services and quality of life that are generated through local sales tax collections. Thus, outshoppers may become aware of the benefits of shopping in town and its effect on the local quality of life of the town's residents.

\section{Figure 2}

\section{Strategies for Small Town Merchants}

to Retain Outshoppers

- Cooperative promotional compaigns

- Increase merchandise selection

- Increase fashionable merchandise

- Offer special and custom orders

- Do not change prices

- Increase shopping excitement

- Be more service-oriented

- Train sales personnel properly

Outshoppers also displayed displeasure with the local sales personnel and lack of fun and excitement in shopping. By bringing in special attractions and/or festivals into malls and shopping areas, more enthusiasm about shopping in the local area should result. Also additional emphasis on being served by service-oriented and courteous sales personnel should generate a more favorable response by outshoppers.

\section{Large City Merchants' Strategies for Attracting Outshoppers}

With the intense competition in larger city trading areas, merchants may feel that it's worth the effort to look "in their own backyards" for additional customers. The findings of the study imply that the larger metropolitan areas are successfully attracting the male outshopper. In particular, single males appear to be a very promising customer base. In regard to strategies aimed at attracting male outshoppers, there is no indication of needed changes in pricing or location by larger city merchants. Changes in marketing strategies are needed in the areas of advertising, services, and 
credit policies. It may be possible to attract more outshoppers with promotions aimed at the out-of-town market. The out-of-town merchant should consider advertising in the outshoppers' home town areas. The additional advertising might increase sales to higher levels. An intensive direct mail campaign could be used to attract outshoppers with preapproved credit cards. Additional sales may also occur when outshoppers are offered a toll free number for phone order and free delivery of large dollar value purchases.

Figure 3

Strategies for Small Town Merchants to Attract Outshoppers

- Advertise in local small town media

- Offer credit cards to out-of-town customers through direct mail

- Offer free out-of-town delivery

- Emphasize selection and fashion in advertising to outshoppers

- Do not change prices

- Employ cooperative advertising among large city merchants to specifically attract outshoppers in local media

- Provide toll free telephone numbers

As intracity competition increases among the merchants in larger cities, outlying areas have the potential to provide lucrative markets for increasing sales volume. Rather than ignoring the outshopper, strategies should be undertaken to attract larger numbers of outshoppers. Additional sales may also be generated through cooperative efforts among large city merchants. Through ads placed in the small town newspapers and radio stations, outshoppers will be more aware of a wide variety of shopping opportunities. Since small town media have lower rates than large cities, the additional advertising costs may be feasible by many merchants through horizontal cooperative advertising. Thus, by attracting this viable market segment, large city merchants may profit greatly without large capital expenditures.

\section{References}

1. Darden, W. R. and W. D. Perreault, Jr. "Identifying Interurban Shoppers: Multiproduct Purchase Patterns and Segmentation Profiles." Journal of Marketing Research, Vol. 13 (February, 1976), pp. 51-60.

2. Herrman, R. D. and L. L. Beik. "Shopper Movements Outside Their Local Retail Area." Journal of Marketing, Vol. 32 (October, 1968), pp. 45-51. 
3. Papodopoulos, N. G. "Consumer Outshopping Research: Review and Extension." Journal of Retailing, Vol. 56 (Winter, 1980), pp. 41-58.

4. Reynolds, F. D. and W. R. Darden. "Intermarket Patronage: A Psychographic Study of Consumer Outshoppers." Joumal of Marketing, Vol. 36 (October, 1972), pp. 50-54.

5. Samali, S. C. and E. B. Uhr. "The Outshopping Spectrum: Key for Analyzing Intermarket Leakages." Journal of Retailing, Vol. 50 (Summer, 1974), pp. 7080.

6. Thompson, J. R. "Characteristics and Behavior of Outshopping Consumers." Journal of Retailing, Vol. 47 (Spring, 1971), pp. 70-80. 